\title{
NUMERICAL INVESTIGATION OF THE BOUSSINESQ - LOVE MATHEMATICAL MODELS ON GEOMETRICAL GRAPHS
}

\author{
A.A. Zamyshlyaeva, A.V. Lut
}

South Ural State University, Chelyabinsk, Russian Federation

E-mail: zamyshliaevaaa@susu.ru, lutti74@rambler.ru

\begin{abstract}
The article is devoted to the numerical investigation of the Boussinesq - Love mathematical models on geometrical graphs representing constructions made of thin elastic rods. The first paragraph describes the developed algorithm for numerical solution of the Boussinesq - Love equation with initial conditions and boundary conditions in the vertices. The block diagram of the algorithm is given and described. The result of computation experiment is given in the second paragraph.
\end{abstract}

Keywords: geometrical graph; the Sobolev type model; the Sturm - Liouville problem; the Boussinesq - Love mathematical model.

Introduction. Consider a finite connected oriented graph $G=\{\mathfrak{V}, \mathfrak{E}\}$, where $\mathfrak{V}=\left\{V_{i}\right\}$ is a set of vertices, and $\mathfrak{E}=\left\{E_{i}\right\}$ is a set of edges. Each edge is characterized by two numbers $l_{j}, d_{j} \in \mathbb{R}_{+}$, denoting the length and cross-sectional area of the edge $E_{j}$ respectively. On a graph $G$ consider the Boussinesq - Love equation $[1,2]$

$$
\lambda u_{t t}-u_{x x t t}=\alpha u_{x x}, \quad u=\left(u_{1}, u_{2}, \ldots, u_{j}, \ldots\right)
$$

with the following conditions at each vertex $V_{i}$

$$
\begin{gathered}
\sum_{E_{j} \in E^{a}\left(V_{i}\right)} d_{j} u_{j x}(0, t)-\sum_{E_{m} \in E^{\omega}\left(V_{i}\right)} d_{m} u_{m x}\left(l_{m}, t\right)=0, \\
u_{j}(0, t)=u_{k}(0, t)=u_{m}\left(l_{m}, t\right)=u_{n}\left(l_{n}, t\right)
\end{gathered}
$$

and initial conditions

$$
\begin{aligned}
u(x, 0) & =\varphi(x), \\
u_{t}(x, 0) & =\psi(x) .
\end{aligned}
$$

Here (2) indicates that the flow through each vertex must be equal to zero, and condition (3) indicates that the solution $u=\left(u_{1}, u_{2}, \ldots, u_{j}, \ldots\right)$ at each vertex must be continuous. Conditions $(4)-(5)$ set the initial state and initial velocity at each edge of the graph respectively. Coefficients $\alpha, \lambda$ characterize properties of the material of construction's elements. The function $u(x, t)$ shows the longitudinal displacement of the point $x$ in the $j$-th element of the construction at the moment $t$.

Abstract results on the Sturm - Liouville problem on geometrical graphs were given in [3]. The analytical solution of (1) - (5) using the theory of relatively polynomially bounded operator pencils was held in [4]. Articles [5,6] present algorithms of numerical modelling of the Boussinesq - Love mathematical models on a segment, disc or rectangle. 
Further investigations [7] were devoted to the solution of (1) - (5) on geometrical graphs using the Fourier method with its justification for several graphs. It should be noted that (1) is a Sobolev type equation. The paper presents an algorithm for numerical solution of the stated problem compared to different methods of investigation of Sobolev type equations developed in [8-10].

1. Algorithm of Numerical Method. Let us describe the algorithm of numerical solution of (1) - (5) step by step according to each block of the diagram showed in (Fig. 1).

Start of the program.

Step 1. Input of inital data: number of edges and vertices of the graph, number of summands in Galerkin sum, time period, parameters of the equation $\lambda, \alpha$, using the commands of the attached software bundle "Maplets[Elements]".

Step 2. Selection of the matrix of incidence depending on number of edges and vertices.

Step 3. In dependence on number of edges of the graph input of their lengths using commands of the attached software bundle "Maplets[Elements]".

Step 4. Formulation of the Sturm - Liouville problem. In a cycle by number of edges generation of equations $\left(\mathbb{X}^{k}\right)^{\prime \prime}+\lambda_{k} \mathbb{X}^{k}=0$ and conditions of the form (2), (3).

Step 5. Solution of the Sturm - Liouville problem for the presented graph. The algorithm was described in [7].

Step 6. Formulation of the Boussinesq - Love equation (1) using input parameters.

Step 7. Representation of the solution as a Galerkin sum using the command "sum(...)" for each edge in a cycle and substitution of this representation into equation (1).

Step 8. Input of initial functions for the conditions (4), (5) using the commands of the attached software bundle "Maplets[Elements]".

Step 9. Verification if input on step 8 initial functions satisfy conditions (2), (3) using command "if". If so then go to the next step. Otherwise go to step 17.

Step 10. Let $k=0$.

Step 11. Cycle "for" by $k \leq N$. Scalar multiplication of the obtained on step 7 equations, and input on step 8 initial functions by eigenfunctions obtained on step 5, using the command "int (...)".

Step 12. Verification of degeneracy of the equation, i.e. checking of the condition $\lambda_{k}=-\lambda$, using the command "if". If so, then go to the next step. Otherwise, go to step 14.

Step 13. Verification of belonging of the functions $\varphi_{k}, \psi_{k}$ to the phase space of the equation, using the commands "if" and "int(...)". If so, then go to the next step. Otherwise, go to step 17.

Step 14. Obtaining of initial conditions for the ODE.

Step 15. Solution of ODE with initial conditions using the command "dsolve(...)".

Step 16. Increase $k$ by one. End of cycle by $k \leq N$.

Step 17. If there was received "No" on steps 9, 13 then output "No solution" end of program. Otherwise skip this step.

Step 18. Formation of an approximate solution as a Galerkin sum.

Step 19. Output of the solution on the screen and building of the animation of the approximate solution in time using "animate(plot, ...)".

End of program. 


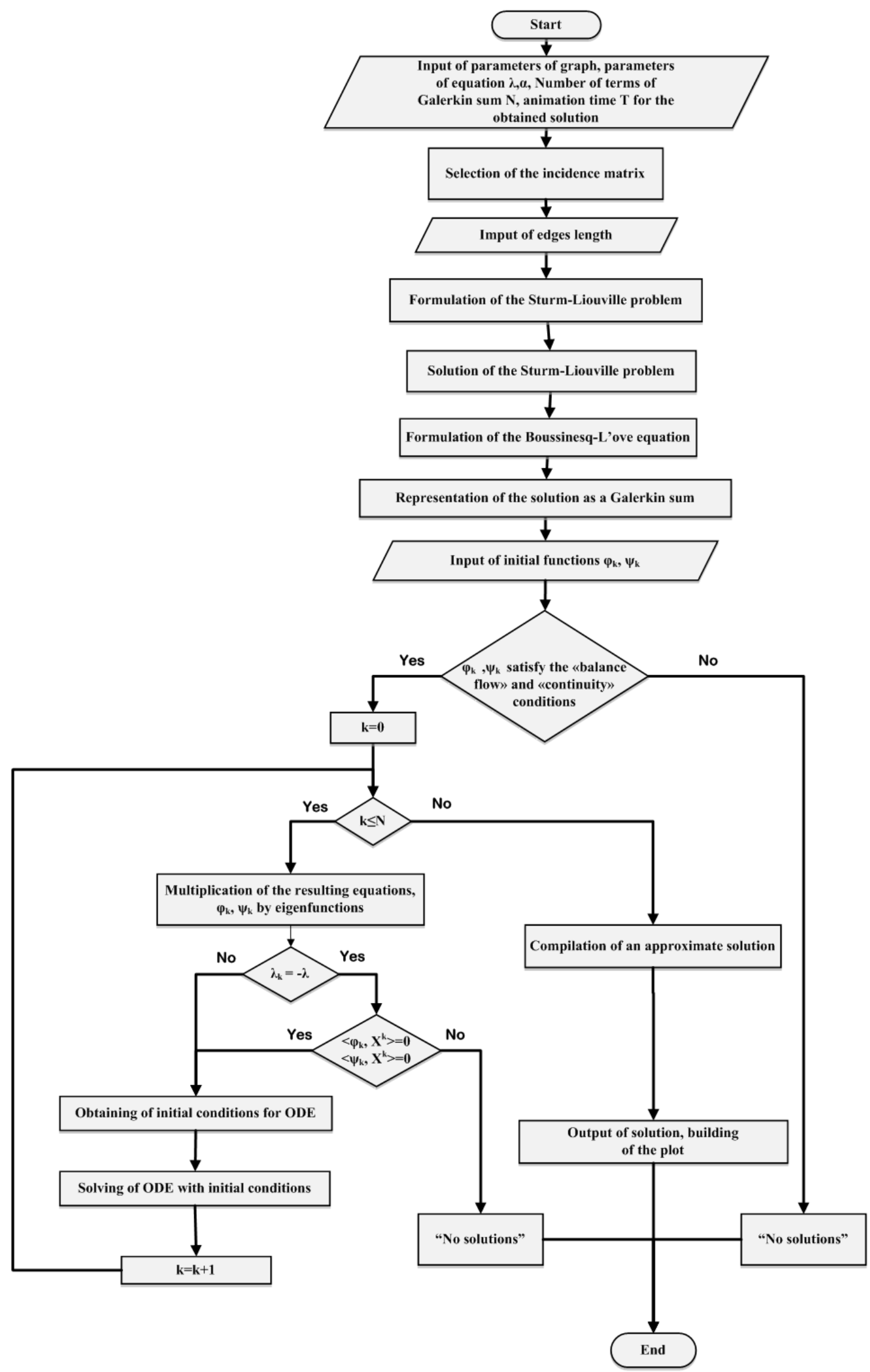

Fig. 1. Block-diagram of the algorithm 
2. Computational experiment. Present the results of computational experiment held using the program that implemented the algorithm above.

Example 1. Let graph $G$ (Fig. 2) consist of three edges with lengths $l_{1}=l_{2}=l_{3}=\pi$, connecting four vertices.

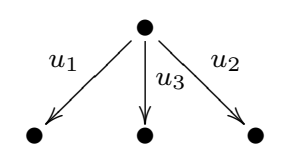

Fig. 2. Graph G

Consider the Boussinesq - Love equation (1) on graph $G$ with parameters $\alpha=3, \lambda=2$ :

$$
2 u_{t t}-u_{x x t t}=3 u_{x x}, \quad u=\left(u_{1}(x, t), u_{2}(x, t), u_{3}(x, t)\right) .
$$

Conditions (2), (3) get the form

$$
\begin{gathered}
u_{1 x}(\pi, t)=0, \quad u_{2 x}(\pi, t)=0, \quad u_{3 x}(\pi, t)=0, \quad u_{1 x}(0, t)+u_{2 x}(0, t)+u_{3 x}(0, t)=0, \\
u_{1}(0, t)=u_{2}(0, t)=u_{3}(0, t) .
\end{gathered}
$$

Let the initial functions for (4), (5) be as follows:

$$
\begin{gathered}
u(x, 0)=\{1 / 4(\cos (2 x)+\cos (x)), 1 / 4(\cos (2 x)+\cos (x)), 1 / 4(\cos (2 x)+\cos (x))\}, \\
u_{t}(x, 0)=\{\cos (x), \cos (x), \cos (x)\} .
\end{gathered}
$$

The program finds four families of eigenvalues

$$
\lambda_{k}^{1}=\frac{\left(\frac{\pi}{2}+2 \pi k\right)^{2}}{\pi^{2}}, \lambda_{k}^{2}=\frac{\left(-\frac{\pi}{2}+2 \pi k\right)^{2}}{\pi^{2}}, \lambda_{k}^{3}=\frac{(\pi+2 \pi k)^{2}}{\pi^{2}}, \lambda_{k}^{4}=4 k^{2}, k=0,1, \ldots
$$

and the following eigenfunctions:

$$
\begin{array}{ll}
\text { If } \cos \left(\sqrt{\lambda_{k}^{m}} x\right) \neq 0 & \text { If } \cos \left(\sqrt{\lambda_{k}^{m}} x\right)=0 \\
X_{1}^{k m}=\frac{-C_{1} \cos \left(-\sqrt{\lambda_{k}^{m}} \pi+\sqrt{\lambda_{k}^{m}} x\right)+3 C_{1} \cos \left(\sqrt{\lambda_{k}^{m}} \pi+\sqrt{\lambda_{k}^{m}} x\right)}{2 \cos \left(\sqrt{\lambda_{k}^{m}} \pi\right)}, & X_{1}^{k m}=C_{1} \sin \left(\sqrt{\lambda_{k}^{m}} x\right), \\
X_{2}=\frac{C_{1} \cos \left(-\sqrt{\lambda_{k}^{m}} \pi+\sqrt{\lambda_{k}^{m}} x\right)}{\cos \left(\sqrt{\lambda_{k}^{m}} \pi\right)}, & X_{2}^{k m}=0, \\
X_{3}^{k m}=\frac{C_{1} \cos \left(-\sqrt{\lambda_{k}^{m}} \pi+\sqrt{\lambda_{k}^{m}} x\right)}{\cos \left(\sqrt{\lambda_{k}^{m}} \pi\right)}, & X_{3}^{k m}=C_{1} \sin \left(\sqrt{\lambda_{k}^{m}} x\right),
\end{array}
$$

where $C_{1}$ is a constant which can be found from the normalization condition for the eigenfunctions in $L_{2}, m=1, \ldots, 4$.

An approximate solution will be searched in the form

$$
u(x, t)=\sum_{k=0}^{3} \sum_{m=1}^{4} T^{k m}(t) \mathbb{X}^{k m}(x),
$$

where $\mathbb{X}^{k m}(x)=\left(X_{1}^{k m}(x), X_{2}^{k m}(x), X_{3}^{k m}(x)\right), k=0, \ldots, 3, m=1, \ldots, 4$ are the orthonormed eigenfunctions of the operator $-\frac{\partial^{2}}{\partial x^{2}}$, i.e. satisfying equation

$$
\left(\mathbb{X}^{k m}\right)^{\prime \prime}+\lambda_{k}^{m} \mathbb{X}^{k m}=0
$$

and conditions (2), (3), the functions $T^{k m}(t)$ depend only on $t$. 
There was received the following solution of $(1)-(5)$ on graph $G$ :

$$
\begin{aligned}
u_{1}= & \frac{\sqrt{6}}{8} \cos \left(\frac{3 \sqrt{33}}{11} t\right) \sin \left(\frac{5}{2} x\right)+\frac{\sqrt{6}}{8} \cos \left(\frac{3 \sqrt{33}}{11} t\right) \sin \left(\frac{3}{2} x\right)+ \\
& +\frac{1}{4} \cos \left(\frac{3 \sqrt{33}}{11} t\right) \cos (2 x)+\frac{1}{4} \cos \left(\frac{3 \sqrt{33}}{11} t\right) \cos (3 x) \\
u_{2} & =\frac{1}{4} \cos \left(\frac{3 \sqrt{33}}{11} t\right) \cos (2 x)+\frac{1}{4} \cos \left(\frac{3 \sqrt{33}}{11} t\right) \cos (3 x) \\
u_{3}=- & \frac{\sqrt{6}}{8} \cos \left(\frac{3 \sqrt{33}}{11} t\right) \sin \left(\frac{5}{2} x\right)-\frac{\sqrt{6}}{8} \cos \left(\frac{3 \sqrt{33}}{11} t\right) \sin \left(\frac{3}{2} x\right)+ \\
& +\frac{1}{4} \cos \left(\frac{3 \sqrt{33}}{11} t\right) \cos (2 x)+\frac{1}{4} \cos \left(\frac{3 \sqrt{33}}{11} t\right) \cos (3 x) .
\end{aligned}
$$

Its graphs at different time moments are shown in Fig. 3 - Fig. 6.

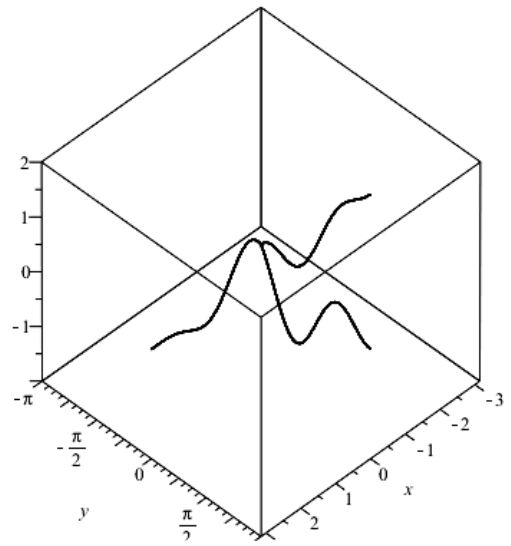

Fig. 3. Solution at $\mathrm{t}=0$

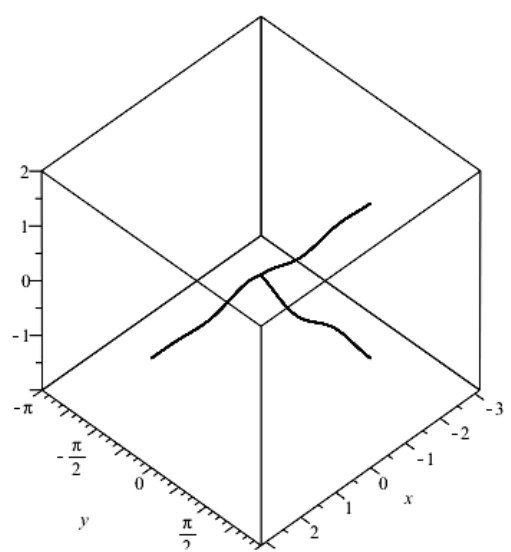

Fig. 5. Solution at $\mathrm{t}=15$

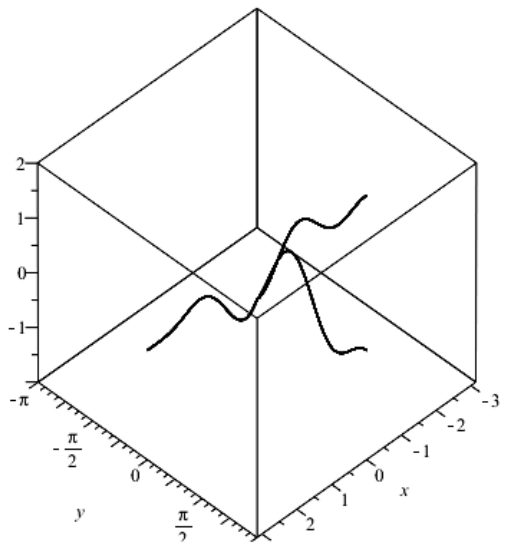

Fig. 4. Solution at $t=10$

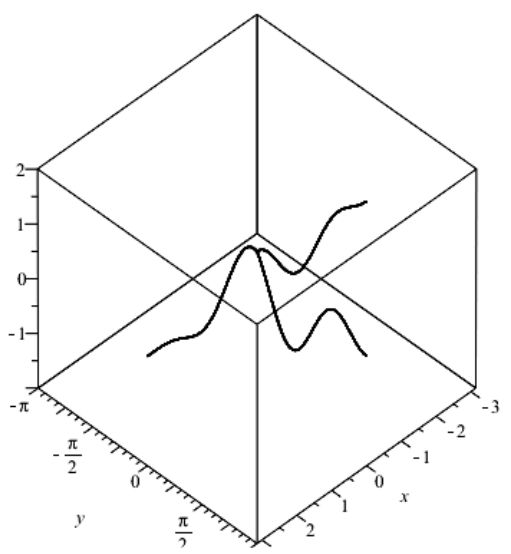

Fig. 6. Solution at $\mathrm{t}=20$

Acknowledgements. The work was supported by Act 211 Government of the Russian Federation, contract No. 02.A03.21.0011. 


\title{
References
}

1. Love A.E.H. A Treatise on the Mathematical Theory of Elasticity. Cambridge, At the University Press, 1927.

2. Uizem G. Linear and Nonlinear Waves. M., Mir, 1977.

3. Bayazitova A.A. The Sturm - Liouville Problem on Geometric Graph. Bulletin of the South Ural State University. Series: Mathematical Modelling, Programming and Computer Software, 2010, no. 16 (192), issue 5, pp. 4-10. (in Russian)

4. Zamyshlyaeva A.A., Sviridyuk G.A. Nonclassical Equations of Mathematical Physics. Linear Sobolev Type Equations of Higher Order. Bulletin of the South Ural State University. Series: Mathematics. Mechanics. Physics, 2016, vol. 8, no. 4, pp. 5-16. DOI: 10.14529/mmph160401

5. Zamyshlyaeva A.A. On Algorithm of Numerical Modelling of the Boussinesq - Love Waves. Bulletin of the South Ural State University. Series: Computer Technologies, Automatic Control and Radioelectronics, 2013, vol. 13, no. 4, pp. 24-29. (in Russian)

6. Zamyshlyaeva A.A., Surovtsev S.V. Finding of a Numerical Solution to the Cauchy - Dirichlet Problem for Boussinesq - Love Equation Using Finite Difference Method. Bulletin of the Samara State University. Natural Science Series, 2015, no. 6, pp. 76-81. (in Russian)

7. Zamyshlyaeva A.A., Lut A.V. Boussinesq - Love Mathematical Model on a Geometrical Graph. Journal of Computational and Engineering Mathematics, 2015, vol. 2, no. 2, pp. 82-97. DOI: $10.14529 /$ jcem 150208

8. Demidenko G.V., Uspenskii S.V. Partial Differential Equations and Systems not Solvable with Respect to the Highest Order Derivative. N.Y., Basel, Hong Kong, Marcel Dekker, 2003.

9. Showalter R.E. Hilbert Space Methods for Partial Differential Equations. London, Pitman Publ., 1977.

10. Al'shin A.B., Korpusov M.O., Sveshnikov A.G. Blow-up in Nonlinear Sobolev Type Equations. Berlin, N.Y., De Gruyter, 2011. DOI: 10.1515/9783110255294

Received March 2, 2017

УДК 517.9

DOI: $10.14529 / \mathrm{mmp} 170211$

\section{ЧИСЛЕННОЕ ИССЛЕДОВАНИЕ МАТЕМАТИЧЕСКИХ МОДЕЛЕЙ БУССИНЕСКА - ЛЯВА НА ГЕОМЕТРИЧЕСКИХ ГРАФАХ}

\author{
А.А. Замыиляева, А.В. Лут
}

Южно-Уральский государственный университет, г. Челябинск

Статья посвящена численному исследованию математических моделей Буссинеска - Лява на геометрических графах, описывающих конструкции, состоящие из тонких упругих стержней. В первом параграфе представлен разработанный алгоритм для численного решения уравнения Буссинеска - Лява с начально-краевыми условиями в виде схемы, с последующим описанием. Во втором параграфе приведен результат вычислительного эксперимента, полученный с помощью программы, реализующей данный алгоритм.

Ключевые слова: геометрический граф; модель соболевского типа; задача Штурма - Лиувилля; уравнение Буссинеска - Лява. 


\section{Литература}

1. Математическая теория упругости / А. Ляв. - М.; Л.: ОНТИ, 1935. - 674 с.

2. Уизем, Дж. Линейные и нелинейные волны / Дж. Уизем. - М.: Мир, 1977.

3. Баязитова, А.А. Задача Штурма - Лиувилля на геометрическом графе / А.А. Баязитова // Вестник ЮУрГУ. Серия: Математическое моделирование и программирование. 2010. - № 16 (192), вып. 5. - С. 4-10.

4. Zamyshlyaeva, A.A. Nonclassical Equations of Mathematical Physics. Linear Sobolev Type Equations of Higher Order / А.A. Zamyshlyaeva, G.A. Sviridyuk // Вестник ЮУрГУ. Серия: Математика. Механика. Физика. - 2016. - Т. 8, № 4. - С. 5-16.

5. Замышляева, А.А. Об алгоритме численного моделирования волн Буссинеска - Лява / А.А. Замышляева // Вестник ЮУрГУ. Серия: Компьютерные технологии, управление, радиоэлектроника. - 2013. - Т. 13, № 4. - С. 24-29.

6. Замышляева, А.А. Нахождение численного решения задачи Коши - Дирихле для уравнения Буссинеска - Лява методом конечных разностей / А.А. Замышляева, С.В. Суровцев // Вестник Самарского университета. Естественнонаучная серия. - 2015. - № 6. C. $76-81$.

7. Zamyshlyaeva, A.A. Boussinesq - Love Mathematical Model on a Geometrical Graph / A.A. Zamyshlyaeva, A.V. Lut // Journal of Computational and Engineering Mathematics. 2015. - V. 2, № 2. - P. 82-97.

8. Demidenko, G.V. Partial Differential Equations and Systems not Solvable with Respect to the Highest Order Derivative / G.V. Demidenko, S.V. Uspenskii. - N.Y.; Basel; Hong Kong: Marcel Dekker, 2003.

9. Showalter, R.E. Hilbert Space Methods for Partial Differential Equations / R.E. Showalter. - London: Pitman Publ., 1977.

10. Al'shin, A.B. Blow-up in Nonlinear Sobolev Type Equations /A.B. Al'shin, M.O. Korpusov, A.G. Sveshnikov. - Berlin; N.-Y.: De Gruyter, 2011.

Алена Александровна Замышляева, доктор физико-математических наук, доцент, кафедра «Прикладная математика и программирование», ЮжноУральский государственный университет (г. Челябинск, Российская Федерация), zamyshliaevaaa@susu.ru.

Александр Валерьевич Лут, студент, Южно-Уральский государственный университет (г. Челябинск, Российская Федерация), lutti74@rambler.ru.

Поступила в редакцию 2 марта 2017 г. 